\title{
Video Media Assisted Example Non Example Model on Mathematics Learning Outcomes
}

\author{
Desak Kadek Suciani1 ${ }^{1}$ Ni Wayan Rati², I Gde Wawan Sudatha ${ }^{3}$
}

1,2Study Program of Primary School Education Teachers, Faculty of Education, Ganesha University of Education, Singaraja, Indonesia

${ }^{3}$ Study Program of Education Technology, Ganesha University of Education, Singaraja, Indonesia

\begin{tabular}{l} 
A R T I C L E I N F O \\
\hline Article history: \\
Received 18Desember \\
2019 \\
Received in revised form \\
30 December 2019 \\
Accepted 15January 2020 \\
Available online 20 \\
February 2020 \\
kata kunci: \\
example non example, \\
matematika, video \\
Keywords: $\quad$ non Example, \\
Example nathematics, Video
\end{tabular}
Hasil penelitian membuktikan bahwa model pembelajaran example non example
berbantuan media video memberikan pengaruh terhadap hasil belajar matematika.Hasil penelitian ini dapat dijadikan landasan teori atapun pedoman pembelajaran selanjutnya untuk meningkatkan hasil belajar khususnya matematika.

\begin{abstract}
A B S T R A K
Rata-rata hasil belajar matematika kelas $\mathrm{V}$ tergolong rendah. Hal tersebut dikarenakan ketakutan siswa untuk belajar dan guru belum maksimal dalam menciptakan suasana menyenangkan. Penelitian ini bertujuan untuk memahami hasil belajar matematika antara siswa yang dibelajarkan dengan model pembelajaran example non example berbantuan media video dengan siswa yang dibelajarkan model discovery learning berbantuan media video pada mata pelajaran matematika siswa kelas V. Penelitian ini termasuk eksperimen semu menggunakan desain non-equivalent post-test only control group design dengan populasinya siswa kelas V berjumlah 128 siswa. Pengambilan sampel menggunakan teknik random sampling, dengan jumlah 43 siswa. Data hasil belajar matematika dikumpulkan dengan metode tes yaitu dengan tes objektif pilihan ganda. Data hasil belajar matematika dianalisis menggunakan uji-t polled varians. Berdasarkan uji-t diperoleh thitung $=7,78>$ tabel $=2,021$ pada taraf signifikansi $5 \%(\alpha=0,05)$ dengan $d b=n 1+n 2-2=43-2=41$ maka H0 ditolak.
\end{abstract}

\section{A B S T R A C T}

The average grade of learning outcomes in class $V$ is low. That is because students' fear of learning and the teacher is not optimal in creating a pleasant atmosphere. This study aims to understand mathematics learning outcomes between students who are taught with example non example learning models assisted with video media and students who are taught discovery learning models assisted with video media in the mathematics subjects of class V. This study includes quasi-experimental uses non-equivalent post designs test only control group design with a population of class V students totaling 128 students. Sampling using a random sampling technique, with a total of 43 students. Mathematics learning outcome data is collected by a test method that is multiple choice objective tests. Mathematical learning outcomes data were analyzed using polled variance t-test. Based on the t-test obtained $t$ count $=7.78>\mathrm{t}$ table $=2.021$ at a significance level of $5 \%(\alpha=0.05)$ with $\mathrm{db}=\mathrm{n} 1+\mathrm{n} 2-2=43-2=41$ then $\mathrm{H} 0$ is rejected. The results of the study prove that the example non example learning model assisted by video media influences on mathematics learning outcomes. The results of this study can be used as a theoretical basis or further learning guidelines to improve learning outcomes, especially mathematics.

\section{Introduction}

Mathematics is one of lessons taught for elementary school students. (Jannah \& Morina, 2020) Mathematics is a basic learning that must be taught from the elementary school level because it is very closely related to daily life. Unconsciously mathematics has entered into the world of children before entering the world of school. Sarah (2017) states that mathematics is a science explaining numbers and calculations, numerical problems, regarding quantity, studying the relationship of patterns, shapes and structures, means of thinking, collection of systems, and structure of tools. Mathematics learning in primary schools trains students to relate obtained theory at school to real-life at home or in the community (Aisyah Wiyono, Mustamin Anggo, 2018). In addition, according to (Suarjana \& Japa, 2015) mathematics can also train the students' critical thinking in solving problems regarding numbers, patterns, shapes, tables, and so on. According to Suryabrata (Rinaldy, 2019) mathematics learning requires some supporting factors so that learning becomes more meaningful, one of which is from the

Copyright (C) Universitas Pendidikan Ganesha. All rights reserved. 
teacher and student learning environment. It is because there are still many students who are afraid to learn mathematics. The teachers often scold them since they cannot answer the questions. The teacher cannot use media to attract students in learning mathematics. However, many students find it difficult in learning mathematics because the abstract objects are difficult for students to understand so that student learning outcomes tend to be low. It is in line with a study conducted by (Ulhusna \& Diana, 2020), mathematics is one of difficult and frightening subjects so that students feel uncomfortable and compelled to learn. It can indirectly affect student learning outcomes.

Based on observation and interview that have been conducted with the fifth grade teachers in Group IV of Buleleng District on November $20^{\text {th }}$ and $21^{\text {st }} 2019$, the following results were obtained. (a) The results of the interview found that (1) Many students were afraid of learning mathematics, (2) Students were less creative and innovative. It was because when a test was given by the teacher, students could not do it unless an example was given first. (3) Did not understand the story matter well. Students who were given examples of story problems could be understood but, if the words in the story problems were reversed then the students could not answer the questions. (4) The impact of the four problems was decreased student learning outcomes. (b) The conducted results of observation, it was known that most students were afraid of learning mathematics. The causes were: 1 ) the model used by the teacher was monotonous, namely lectures and assignments. 2) learning was done using only a source from textbooks. 3) the use of less attractive media. It affects on the lack of material understanding, especially in mathematics so that learning outcomes were low. Besides, interview and observation activities, the data were strengthened by recording documents containing the KKM (standard of minimum completeness of mastery learning) and the level of completeness and incompleteness of middle test results, the document can be seen in Table 1 as follows.

Table 1. The Learning Result of Mathematics Middle Test of the Fifth Grade in Cluster IV in Buleleng District

\begin{tabular}{cccccccc}
\hline No. & Schools & $\begin{array}{c}\text { Grad } \\
\text { e }\end{array}$ & $\begin{array}{c}\text { KKM } \\
\text { Comple } \\
\text { te }\end{array}$ & $\begin{array}{c}\text { Percentage } \\
(\%)\end{array}$ & $\begin{array}{c}\text { Incomplet } \\
\text { e }\end{array}$ & $\begin{array}{c}\text { Percentage } \\
(\%)\end{array}$ \\
\hline 1 & SD N 1 Penglatan & V & 60 & 6 & 37,50 & 10 & 62,50 \\
2 & SD N 2 Penglatan & V & 60 & 7 & 31,82 & 15 & 68,18 \\
3 & SD N 3 Penglatan & V & 65 & 5 & 23,81 & 16 & 76,19 \\
4 & SD N 1 Alasangker & V & 63 & 9 & 50,00 & 9 & 50,00 \\
5 & SD N 2 Alasangker & V & 62 & 4 & 14,81 & 23 & 85,19 \\
6 & SD N 3 Alasangker & V & 70 & 7 & 29,17 & 17 & 70,83 \\
\hline
\end{tabular}

Based on the data in Table 01, it can be seen that there is still a gap between expectations and reality. It can be seen clearly the difference in the number of students who complete and incomplete. In addition, the percentage of students who have successfully moved from $14.81 \%$ to $50 \%$, which is categorized as a failure and low. While the percentage of incomplete students is still quite a lot. The lack of teacher in conducting fun learning for students will cause students to get bored and feel afraid of learning mathematics so that learning outcomes are affected. These problems will give an impact on student side starting from difficult mathematics implementation in the community, low learning outcomes, low, lack of understanding of the mathematics meaning in daily life, and can slow down economic activities such as buying and selling activities. Considering the problems above, a certain strategy or way is neeeded to be applied to attract students interent to learn mathematics bravely.

The intended learning outcomes are the changes after teaching and learning process at school. The changes can be in terms of cognitive, affective, and psychomotor that are stated in quantitative or qualitative data. These changes can be felt directly or indirectly. According to Walsiman (Ningrat \& Sumantri, 2018) there are 2 factors influence learning outcomes as follows. Internal factors come from students themselves in learning which include the desire, enthusiasm, motivation, interests, habits, attitudes of physical and health conditions, perseverance and intellectual students. However, external factors are influenced from outside of students such as family, play environment, and community around the residence. These factors will affect student learning outcomes. If these factors tend to be unhealthy, student learning outcomes will be low.

According to Chittenden (Widoyoko, 2011) a way to measure learning outcomes is by giving tests such as written tests, oral tests, or instruction tests. Assignments, performance appraisal, and project appraisal can also be given. Assessment of learning outcomes can be done with tests and non-tests. However, learning outcomes are conducted generally by giving tests. According to (Sudjana, 2010) there are two types of tests, namely; (a) Essay Test, a test that requires answers to explain, discuss, and 
compare their own words and language in the form of an essay. (b) Objective Test, is a type of question that has other forms, namely multiple choice, true-false, short answers, and match.

Learning outcomes can be known through the teaching and learning process. In the teaching and learning process, it requires a certain method/technique used by the teacher. It can be done by applying a cooperative learning model. The learning model is a way for teachers to deliver material distinctively and sequentially manner from beginning to end and it can also apply approaches, strategies, methods, and learning techniques (Ariyanti \& Nurmeidina, 2019). Example non example model consist of interesting pictures and it is related to the discussed material as well as attract student interest in learning.

Huda (Lisnani, 2019) states that example non example model is a way to teach students by using media that can attract students' attention in learning, so that the concept from teacher will be remembered by students and it emphasizes communication. This strategy has the aims to train students in solving problems given by the teacher in the form of pictures or other media that can lead students to think critically. In addition, B. S. Kurniasih (2014) states that this learning model emphasizes students to define a concept from a material. The following strategies can be used to guide students to think more critically, namely examples (examples of concepts being discussed), and non examples (examples of concepts are not discussed). After knowing these important things, it is also necessary to allow students to combine existing concepts with these two examples so that they can find out the correct concepts. This learning model requires students to be good at analyzing an image from an example material and it is not an example picture of the discussed material, and students are also taught to think critically in solving a problem, and this learning model has a connection with the scientific learning applied in the 2013 curriculum, where students are required to think critically and the teacher is only a facilitator when learning takes place (Ahen Hestavia, Syafdi Maizora, 2019). Moreover, Herawati, Anisa, Nurul Astuty Yensi (2019) state that the example non example learning model is a cooperative learning model that implements examples and non examples learning with a rocky picture, so that students understand the taught material concepts by applying concept analysis. Based on the explanation above, the example non example model more emphasis on picture concepts that are packaged into a picture and it will be analyzed and sought the correct concept considering the teacher's guidance. There are several syntax that must be considered in implementing this model.

Aris (2014) describes several syntax of the example non sample model as follows. (1) The teacher prepares an interesting picture and it contains the discussed material. There are two pictures which are discussed and not discussed. (2) The students help teacher to stick a pictures or prepare LCDs so that images can be seen on the projector screen. Meanwhile, other students can form groups of up to 5 people in 1 group. (3) Students are allowed to observe images that have been displayed on a projector screen or images that have been pasted and describe them. (4) The teacher provides paper for students. Through group discussions of 2-3 people, students are assigned to write a description of each picture and the results of the discussion from the image analysis are recorded on paper. (5) Each group will read the results of the discussion so students will practice to convey the results of their group discussions. (6) After finishing delivering the results of the discussion, the teacher reflects on the correct concept related to the picture. (7) The teacher and students conclude the material based on learning objectives. The advantages of this learning model as stated by Huda (Lisnani, 2019) are (1) Students can practice critical thinking through the activity of analyzing images. (2) Students understand the usefulness of the concepts that have been implanted based on basic competencies. (3) Students are allowed to communicate their opinions about the analyzed images based on basic competencies

Many studies had been conducted with this model, Oktavia et al (2019) state that the example non-example scientific model influences student interest in learning, it can be seen from the results of research that shows the $t_{\text {count }}$ is greater than table around 4.802> 2.095. In addition, Syarifah Habibah (2016) states that the example non example model can improve the completeness of student learning outcomes as seen from the average improvement in the results of the study, which is 77.79 and the mortality rate is $90 \%$. Moreover, Noviasari et al (2019) state that the example non example model can improve children's learning outcomes in elementary school with the lowest percentage of $12.08 \%$ to the highest of $94.94 \%$ with an average of $32.98 \%$. In addition, Suyanti, Putri \& Sunary (2017) state that the example non example model can improve student learning outcomes. It can be seen from the results of each cycle of research that have increased. Based on the previous studies, this model can be used as an alternative learning. The learning process is not only intended to reveal the learning model, but the media also play an important role in the learning process. One type of media that can be applied is Video media

Mayer, Khairani Miftahul, Sutisna (2019) argue that video media is a tool used by teachers to facilitate the material delivery. Video media is a complex media that can be seen and heard by students 
so that the learning is done through listening or seeing pictures (Deliany et al., 2019), learning video media combines moving images with sound and make it easier for students to learn multimedia in which the students can see directly the picture or concept that will be given and can listen to the explanation of the picture. Video media are used to convey concepts that have already existed in audiovisual form, it is because the fifth grade children will certainly want to learn if the media is interesting for students and it is easily understood by all students. In addition, video media emphasize on the material along with supporting pictures of the material.

Khairani Miftahul, Sutisna, (2019) adds that the advantage of using video media is on attracting students interest to learn so that students feel relax in learning. In addition, by displaying videos, learning will be more efficient both from space, time, and messages so that learning can be continued by conveying material that is not yet understood or by discussing videos that have been aired and it can be watched repeatedly. Using video media assisted example non example learning model can increase student activity in the learning process so that the understanding of the material can be well understood and if a test is given, the learning outcomes will be good. A study conducted by Ardiansah (2019) showed that there is a relationship between student interest and learning outcomes after being given treatment in the form of video media in the learning process. In addition, Yunita \& Wijayanti (2017) argue that video media has a great influence on the results of natural science learning. It can be seen that there is an average difference between the experimental class and control class. Another study also stated that video media can influence learning outcomes which is seen from 85.53 where the level of student completeness increases 78\%, (Tasmalina \& Prabowo, 2018).

From the previous descriptions both about the example non exsample learning model and video media, both have advantages in improving learning outcomes, interest in learning and others. Therefore this study aimed to understand the learning outcomes of mathematics between students who are taught by video media assisted example non example learning model and students who are taught by video media assisted discovery learning model in the mathematics subjects of the fifth grade students in Elementary School Cluster IV Buleleng District. Previous research has combined the example non example model with interesting video media. This learning material was applied to the example non example model assisted by video media, which included elements of cubes and blocks, webs of cubes, and beams and solving problems related to cubes and beams. Sudijono(Lus Viana Dewi, Mochammad Ahied, Irsad Rosidi, 2019) state that there are some steps of the video media assisted example non example model, namely (1) The teacher prepares pictures related to the material, both images related to material and not. (2) The teacher displays the pictures using the LCD. (3) The teacher gives instructions and opportunity for students to pay attention/analyze images. (4) Discussing with groups of 2-3 students. (5) Each group presents the results of the discussion. (6) After understanding the analysis results conducted by students, the teacher begins to explain the material and display videos that are related to the material and discussion of the exact picture. (7) Teachers and students conclude the material related to the learning objectives. So it can be said that video media is very useful in the learning process. Therefore, a lot of research has been done using this media.

\section{Method}

This study was conducted in cluster IV of Buleleng district. It was conducted from January 18th, 2020 to February 7th, 2020 in 2019/2020. The implementation of study was adjusted to the syllabus at school, especially in mathematics learning with 43 students and 6 treatments. The population of the study was all the fifth grade students in cluster IV of Buleleng sub-district with a total of 128 students, random sampling was used to determine the sample. Before determining the sample, it is necessary to conduct an equality test in each class. The equivalence test used was the ANAVA-one-lane test at a significance level of $5 \%$. Based on the equality test, lottery numbers were given to each class to determine the sample and it was drawn to decide the experimental class and the control class. Based on the draw, it was found that SD N 2 Penglatan (Elementary School) became an experimental class that applied video media assisted example non example model while SD N 3 Penglatan became a control class that applied video media assisted discovery learning model.

This study was experimental research. The type of this study was quasi-experimental by using non-equivalent post-test only control group design.

Pada penelitian ini, variabel terikat yang digunakan adalah hasil belajar matematika dengan menggunakan metode pengumpulan data yaitu pemberian tes. Tes merupakan alat yang terdiri dari sekumpulan pertanyaan dan tugas-tugas untuk mengukur siswa dengan menggunakan suatu kriteria, (Koyan, 2012). Tes objektif pilihan ganda berjumlah 20 butir soal dengan 4 option yaitu a, b, c, dan d, yang akan diberikan tanda silang oleh responden. Setiap butir soal memiliki skor 1 (jika benar) dan skor 
0 (jika salah). Untuk mengetahui hasil belajar siswa, jumlah skor keseluruhan dikalikan dengan 5. Dalam pembuatan tes hasil belajar, memerlukan pedoman yang sering disebut kisi-kisi. Kisi-kisi yang dibuat disesuaikan dengan buku pedoman yang ada di sekolah sehingga tes menjadi serasi dengan materi. Kisikisi instrumen tes hasil belajar memuat ranah kognitif C1 (Mengingat), C2 (Memahami), C3 (Menerapkan), C4 (Menganalisis), dan C5 (Menilai). Berikut ini kisi-kisi soal yang digunakan untuk penelitian pada Tabel 02 .

In this study, the dependent variable was mathematics learning outcomes through test distribution. The test is a tool consisting of some questions and assignments to measure students using a criterion, (Koyan, 2012). The multiple choice objective test consisted of 20 items with 4 options, namely a, b, c, and d, which were crossed by the respondent. Each item had a score of 1 (if it was true) and a score of 0 (if it was incorrect). To find out studentlearning outcomes, the total score was multiplied by 5 . In making a test of learning outcomes, a grid was required as guidelines. The grid was adjusted to the manual of the school so that the test was compatible with the material. The learning instrument test grids included cognitive domains C1 (Remembering), C2 (Understanding), C3 (Applying), C4 (Analyzing), and C5 (Assessing). The question grids in this study can be seen in Table 2 .

Tabel 2. Questions Grids

\begin{tabular}{|c|c|c|c|c|c|c|c|}
\hline No. & & asic Competency & & Indicator & $\begin{array}{l}\text { Cognitive } \\
\text { Domain }\end{array}$ & $\begin{array}{l}\text { Question } \\
\text { Number }\end{array}$ & $\begin{array}{l}\text { Question } \\
\text { Total }\end{array}$ \\
\hline \multirow[t]{6}{*}{1.} & 3.5 & $\begin{array}{l}\text { Explaining, and } \\
\text { determining the }\end{array}$ & 3.5 .1 & $\begin{array}{l}\text { Explaining the } \\
\text { elements of the cube }\end{array}$ & $\mathrm{C} 2$ and $\mathrm{C} 3$ & $1,2,3$ & 3 \\
\hline & & $\begin{array}{l}\text { volume of } \\
\text { building space }\end{array}$ & 3.5 .2 & $\begin{array}{l}\text { Determining the } \\
\text { volume of the cube }\end{array}$ & $\mathrm{C} 2$ and $\mathrm{C} 3$ & $4,5,6,7$ & 4 \\
\hline & & $\begin{array}{l}\text { using volume } \\
\text { units (such as }\end{array}$ & 3.5 .3 & $\begin{array}{l}\text { Describing the } \\
\text { elements of beam }\end{array}$ & $\mathrm{C} 2$ & 8 & 1 \\
\hline & & unit cubes) & 3.5 .4 & $\begin{array}{l}\text { Determining the } \\
\text { volume of beam }\end{array}$ & C3 & 9,10 & 2 \\
\hline & & & 3.5 .5 & $\begin{array}{l}\text { Determining the } \\
\text { volume of irregular } \\
\text { building }\end{array}$ & C5 & 15 & 1 \\
\hline & & & 3.5 .6 & $\begin{array}{l}\text { Solving problems } \\
\text { related to building } \\
\text { volume using unit } \\
\text { cubes }\end{array}$ & $\mathrm{C} 4$ & 13,14 & 2 \\
\hline \multirow[t]{5}{*}{2} & 3.6 & $\begin{array}{l}\text { Explaining and } \\
\text { finding out the } \\
\text { net a simple }\end{array}$ & 3.6 .1 & $\begin{array}{l}\text { Identifying the } \\
\text { properties of the } \\
\text { cube }\end{array}$ & $\mathrm{C} 2$ and $\mathrm{C} 4$ & 17,18 & 2 \\
\hline & & $\begin{array}{l}\text { building (cube } \\
\text { and beam) }\end{array}$ & 3.6 .2 & $\begin{array}{l}\text { Analyzing the net of } \\
\text { the cube }\end{array}$ & $\mathrm{C} 4$ and $\mathrm{C} 5$ & 21,24 & 2 \\
\hline & & & 3.6 .3 & $\begin{array}{l}\text { Identifying the } \\
\text { properties of beam }\end{array}$ & $\mathrm{C} 2$ & 16 & 1 \\
\hline & & & 3.6 .4 & $\begin{array}{l}\text { Analyzing the net of } \\
\text { beam }\end{array}$ & $\mathrm{C} 4$ and $\mathrm{C} 5$ & 20,23 & 2 \\
\hline & & & & Total & & & 20 \\
\hline
\end{tabular}

Before the research data collection instruments were used, it was necessary to conduct an expert test by two experts in mathematics. Based on the results of these expert tests, the test instruments were valid with a total of 25 items. All valid tests were conducted instrument trials to schools that were not research samples. The test results were used to find out whether or not the used instruments had already given to students from other schools. In addition to testing the instrument, it is necessary to test items by conducting item validity, reliability, difficulty and different power levels test. Based on the recapitulation result of item validity, there were 20 items that were valid and 5 items were invalid so they must be "Dropped". In this study, 20 items were given to the experimental group and the control group. The reliability test results were 0.403 which was categorized as medium. For the test results of the difficulty level, 20 items were classified easy. For the different power test items, it obtained 2 good questions, 13 good enough questions, and 5 not good enough questions. Thus, 20 items were used to collect the data. The results of this study were analyzed with two analysis, namely descriptive analysis and inferential analysis. In descriptive analysis, it was used to find out the mean, median, mode, standard 
deviation, and variance. However, inferential analysis consisted of data distribution normality test and data homogeneity test. Data normality test is to determine whether the data is normal or not, it is necessary to conduct a data normality test. Chi-Square analysis was used to find out the normality test as suggested by Koyan (2012).

After the data were declared normal, variance homogeneity test was conducted to check the data whether it was homogeneous or not variant. The hypotheses in this study were:

Ha: There was a significant difference in learning outcomes between students who were taught with the video media assisted example non example learning model and students who were taught with the video media assisted discovery learning model in the mathematics subject of the fifth grade elementary school students in Cluster IV of Buleleng District 2019/2020. Ho: There was no difference in learning outcomes between students who were taught with the video media assisted example non example learning model and students who were taught with the video media assisted discovery learning model in the mathematics subject of the fifth grade elementary school students in Cluster IV of Buleleng District 2019/2020 (2012).

T-test with polled variance was applied in this study to test the hypothesis as suggested by Koyan

\section{Result and Discussion}

This study was conducted in the experimental class for 7 meetings with 6 meetings for implementing the Learning Implementation Plan (RPP) and 1 meeting for giving post-test. The analyzed data were Mathematics learning outcomes of the fifth grade from 22 people in the experimental class. It showed showing that the highest score was 90 and the lowest score was 60. Post-test analysis data of the experimental class can be presented in Table 3.

Table 3. Post-test analysis of experimental class

\begin{tabular}{cccccccc}
\hline Interval & $\mathbf{X}$ & $\mathbf{f}$ & $\mathbf{f X}$ & $\mathbf{f k}$ & $\mathbf{x}^{\prime}$ & $\mathbf{f x}^{\prime}$ & $\mathbf{f x}^{\mathbf{2}}$ \\
\hline $\mathbf{9 0} \mathbf{- 9 5}$ & 92,5 & 2 & 185 & 22 & 4 & 8 & 32 \\
$\mathbf{8 4}-\mathbf{8 9}$ & 86,5 & 1 & 86,5 & 20 & 3 & 3 & 9 \\
$\mathbf{7 8}-\mathbf{8 3}$ & 80,5 & 4 & 322 & 19 & 2 & 8 & 16 \\
$\mathbf{7 2}-\mathbf{7 7}$ & 74,5 & 3 & 223,5 & 15 & 1 & 3 & 3 \\
$\mathbf{6 6}-\mathbf{7 1}$ & $\mathbf{6 8 , 5}$ & 8 & 548 & 12 & 0 & 0 & 0 \\
$\mathbf{6 0 - 6 5}$ & 62,5 & 4 & 250 & 4 & -1 & -4 & 4 \\
\hline Total & & $\mathbf{2 2}$ & $\mathbf{1 6 1 5}$ & - & - & $\mathbf{1 8}$ & $\mathbf{6 4}$ \\
\hline
\end{tabular}

Based on the table above, it can be explained that the length of the interval class was 6, with a total frequency of 22 students. From the table above, it is used as a guide to find the mean (73.4), median (70.75), mode (68.07), standard deviation (15.54) and variance (241.49). The study was conducted for 7 meetings with 6 meetings for applying the Learning Implementation Plan (RPP) and 1 meeting for giving post-test. The analyzed data were the results of mathematics learning of the fifth grade students with a total of 21 students in the control class that showed the highest score of 75 and the lowest score of 20. Post-test analysis results of the control class can be presented in Table 4.

Table 4. Post-test analysis data of control class

\begin{tabular}{cccccccc}
\hline Interval & $\mathbf{X}$ & $\mathbf{f}$ & $\mathbf{f X}$ & $\mathbf{f k}$ & $\mathbf{x}^{\prime}$ & $\mathbf{f x}^{\prime}$ & $\mathbf{f x}^{\mathbf{2}}$ \\
\hline $\mathbf{7 0}-\mathbf{7 9}$ & 74,5 & 1 & 74,5 & 21 & 4 & 4 & 16 \\
$\mathbf{6 0}-\mathbf{6 9}$ & 64,5 & 0 & 0 & 20 & 3 & 0 & 0 \\
$\mathbf{5 0}-\mathbf{5 9}$ & 54,5 & 2 & 109 & 20 & 2 & 4 & 16 \\
$\mathbf{4 0 - 4 9}$ & 44,5 & 7 & 311,5 & 18 & 1 & 7 & 49 \\
$\mathbf{3 0 - 3 9}$ & 34,5 & 5 & 172,5 & 11 & 0 & 0 & 0 \\
$\mathbf{2 0}-\mathbf{2 9}$ & 24,5 & 6 & 147 & 6 & -1 & -6 & 36 \\
\hline Total & & $\mathbf{2 1}$ & $\mathbf{8 1 4 , 5}$ & - & - & $\mathbf{9}$ & $\mathbf{1 1 7}$ \\
\hline
\end{tabular}

Berdasakan tabel di atas, dapat dijabarkan bahwa panjang kelas interval yaitu 10, dengan jumlah frekuensi 22 siswa. Dari tabel di atas dijadikan pedoman untuk mencari mean $(37,07)$, median $(34,9)$, Modus (41,21), standar deviasi $(13,92)$ dan varians $(193,77)$.Sebelum melakukan uji hipotesis, data hasil 
belajar perlu dilakukan uji prasyarat seperti uji normalitas sebaran data dan uji homogenitas data.Uji normalitas data dalam penelitian ini menggunakan uji Chi-Square $\left(\mathrm{X}^{2}\right)$ dengan kriteria jika $\mathrm{X}^{2}$ hitung $<\mathrm{X}^{2}$ tabel. Pengujian hipotesisnya yaitu $\mathrm{H}_{0}$ : sampel berasal dari data berdistribusi normal dan $\mathrm{H}_{1}$ : sampel berasal dari data yang tidak berdistribusi normal. Berdasarkan analisis uji normalitas pada kelas eksperimen diperoleh $X^{2}$ hitung $=7,03$ dan $X^{2}$ tabel pada taraf signifikansi 5\% dengan $d k=5$ adalah 11,07 . Sehingga diperoleh $\mathrm{X}^{2}$ hitung $<\mathrm{X}^{2}$ tabel, dapat disimpulkan bahwa data hasil penelitian berdistribusi normal. Sedangkan pada kelas kontrol diperoleh $\mathrm{X}^{2}{ }_{\text {hitung }}=8,50$ dan $\mathrm{X}^{2}$ tabel pada taraf signifikansi $5 \%$ dengan $\mathrm{dk}=5$ adalah 11,07. Sehingga diperoleh $\mathrm{X}^{2}$ hitung $<\mathrm{X}^{2}$ tabel, dapat disimpulkan bahwa data hasil penelitian berdistribusi normal.

Setelah dilakukan uji normalitas sebaran data, selanjutnya melakukan uji homogenitas varians.Uji homogenitas dilakukan dengan menggabungkan data kedua kelompok dengan menggunakan uji-F yang memiliki kriteria jika $\mathrm{f}_{\text {hitung }}<\mathrm{f}_{\text {tabel }}$ maka data tersebut homogen.Berdasarkan analisis di atas, didapatkan harga $F_{\text {hitung }}=1,25$. Selanjutnya harga $F_{\text {tabel }}$ pada taraf signifikansi $5 \%$ dengan $\mathrm{df}_{\text {pembilang }}=\mathrm{k}-1=2-1=1$, dan $\mathrm{df}_{\text {penyebut }}=\mathrm{n}-\mathrm{k}=43-2=41$, didapatkan harga $\mathrm{ftabel}_{\mathrm{f}}=4,08$. Hasil tersebut menunjukkan $\mathrm{f}_{\text {hitung }}<\mathrm{f}_{\text {tabel, }}$, sehingga dapat disimpulkan bahwa kedua kelompok data tersebut homogen.

Berdasarkan hasil uji prasyarat, diperoleh hasil post-test kelompok eksperimen dan kelompok kontrol memiliki distribusi normal dan memiliki varians Setelah memenuhi uji prasyarat, selanjutnya melakukan uji hipotesis dengan menggunakan Uji-t.Rekapitulasi hasil analisis uji hipotesis menggunakan uji-t dapat dilihat pada Tabel 05 sebagai berikut.

Based on the table above, it can be explained that the length of the interval class was 10, with a total frequency of 22 students. From the table above, it was used as a guide to find the mean (37.07), median (34.9), mode (41.21), standard deviation (13.92), and variance (193.77). Before conducting hypothesis testing, data learning outcomes were needed to do prerequisite tests such as test data normality test and data homogeneity test. In this study, normality test applied Chi-Square test $\left(\mathrm{X}^{2}\right)$ with the criteria if $\mathrm{X}^{2}$ count $<\mathrm{X}^{2}$ table. Testing the hypothesis was $\mathrm{H}_{\mathrm{o}}$ : the samples came from normal data distribution and $\mathrm{H}_{1}$ : samples came from data that were not normally distributed. Based on the analysis of normality test in the experimental class, it obtained $\mathrm{X}^{2}$ count $=7.03$ and $\mathrm{X}^{2}$ table at a significance level of $5 \%$ with $\mathrm{dk}=5$ was 11.07. In order to obtain the calculated $\mathrm{X}^{2}<\mathrm{X}^{2}$ table, it can be concluded that the research data were normally distributed. Whereas in the control class $\mathrm{X}^{2}$ count $=8.50$ and $\mathrm{X}^{2}$ table obtained at a significance level of $5 \%$ with $\mathrm{dk}=5$ was 11.07 . In order to obtain the calculated $\mathrm{X}^{2}<\mathrm{X}^{2}$ table, it can be concluded that the research data were normally distributed.

After testing the normality of data distribution, then the variance homogeneity was tested. Homogeneity test was done by combining the data of the two groups using the F-test which had the criteria if $\mathrm{f}_{\text {count }}<\mathrm{ftable}_{\text {te }}$ then the data was homogeneous. Based on the analysis above, the $\mathrm{F}_{\text {count }}$ value $=1.25$ . Furthermore, the price of $\mathrm{F}$ table at the $5 \%$ significance level with df numerator $=\mathrm{k}-1=2-1=1$, and the $\mathrm{df}$ mentioner $=\mathrm{n}-\mathrm{k}=43-2=41$, the $\mathrm{f}_{\text {tabel }}$ value $=4.08$. These results indicate $\mathrm{f}_{\text {count }}<\mathrm{ftable}_{\text {ta }}$, so it can be concluded that the two data groups are homogeneous.

Based on the prerequisite test results, the results of the post-test experimental group and control group have a normal distribution and variance. After fulfilling the prerequisite test, then t-test was applied as follows.

Table 5. The Resut of T-test Recapitulation

\begin{tabular}{lllccccc}
\hline No. & Sample & $\mathrm{N}$ & $\mathrm{dk}$ & $\mathrm{X}$ & $\mathrm{S}^{2}$ & $\mathbf{t}_{\text {count }}$ & $\mathbf{t}_{\text {table }}$ \\
\hline 1 & Experimental & 22 & \multirow{2}{*}{41} & 73,40 & 241,49 & \multirow{2}{*}{7,78} & \multirow{2}{*}{2.021} \\
2 & Control & 21 & & 37,07 & 193,77 & & \\
\hline
\end{tabular}

From the recapitulation of the t-test results analysis in Table 7 showed that tcount $=7.78$ and at $t_{\text {table }}=2.021$ for $\mathrm{dk}=(\mathrm{n} 1+\mathrm{n} 2)-2=41$ at a significance level of $5 \%$. Based on testing criteria, because tcount $>$ ttable, Ho was rejected and Ha was accepted.

It can be concluded that there is a significant difference in learning outcomes between students who are taught with the video media assisted example non example learning model and students who are taught with video media assisted the discovery learning model in the mathematics subject of the fifth grade elementary school students Cluster IV of Buleleng District 2019/2020

Based on study that has been conducted, there are good changes starting from very active and enthusiastic students to participate in learning, it is because all students involved in learning and there is no competition between each group, as well as the use of interesting learning media namely video media in delivering material from the beginning to the end of learning. Group work was formed to solve 
the given problems in training students to interact with each other so that it looks more active. This is in line with a study conducted by Thamrin (2019) entitled The Effectiveness of Using Non-Example Example Cooperative Models in Mathematics Learning for the Seventh Grade Middle School Students with learning outcomes more refers to student learning outcomes, student activities, feasibility, and positive student responses so that student activity increase in the classroom.

A study that had been done in two sample groups was the experimental group that was taught using video media assisted example non example model while the control group was taught using the video media assisted discovery learning model. After being treated for 6 times and post-test, it was found that there were different results between the groups applying video media assisted example non example model and the group applying video media assisted discovery learning model. It can be proven by the results of descriptive statistical analysis of the two sample groups. Descriptively, the average value of the post-test experimental group was 73.40 and the control group was 37,07 . So the average value of the mathematics learning outcomes in the experimental group was (73.40)> the control group (37.07) with a difference of 36.33. It means that the results of the hypothesis test showed $t_{c o u n t}$ of 7.78 and table at a significance level of $5 \%$ with $\mathrm{db}=\mathrm{n} 1+\mathrm{n} 2-2=43-2=41$ is 2.021 . These results showed that $\mathrm{t}_{\text {count }}>\mathrm{t}$ table, so that $\mathrm{HO}$ was rejected and Ha stated that there were significant differences in learning outcomes between students who were taught with the video media assisted example non example learning model and students who were taught with video media assisted discovery learning model in the mathematics subject of the fifth grade elementary school students Cluster IV of Buleleng District 2019/2020. The implemented learning activities in the experimental class applied vieo media assisted example non model that had a positive impact on students.

First, encourage students to think critically. Critical thinking in learning has a large impact including to the correct concepts through image analysis or practice questions conducted in learning, so indirectly critical thinking is very necessary in the learning process. Critical thinking is also presented in this study, it can be seen in the steps of the learning model, namely the activity of analyzing images that require critical thinking to look for differences from the pictures provided by the teacher. It is in line with a study conducted by Ayu Fitri (2020) entitled The Effect of Example Non Example Models on the Ability in Understanding Flat Build Concepts in the Fifth Grade Elementary School Students, it states that the example non example model can train students more critically in analyzing images and provide an opportunity to express opinions after analyzing the picture. The cooperative model using interesting picture is the example non example model (I and B. S. Kurniasih, 2017). In addition, this study is in line with (Lusiani, 2019), entitled The Effect of Learning Models Examples Non Examples Assisted by Educative Film Media on Indonesian Language Writing Skills for the Fourth Grade Elementary School Students in Mengwi School Year 2018/2019, states that this model is very well to be applied to the elementary school children in training students' critical thinking and instill true concepts to students. To ensure interesting images and material, it is presented clearer, video media is used to attracts students 'attention in learning and practice students' critical thinking

Second, trained students to work together and be confident. Collaboration between groups can be felt by students in the learning step of making cube and beam net and solve exercises questions in groups. Cooperation between students is needed in the learning process both in large groups and in small groups. Each learning process requires cooperation in learning to practice student interaction and student socialization so that the source of learning is not only from the teacher but also from classmates. After working together in groups, each group was allowed to present the results of their group discussions. By delivering discussion, it can train students' confidence. This is in line with a study conducted by (Teresia Olivia Oennus, Erni, 2019), it showed that there was an effect of applying the example non example learning model to the learning outcomes of the fifth grade students in SD Negeri 1 Gedong Air in Bandar Lampung City Academic Year 2018/2019. This can be proven by increasing student activities in the classroom. In addition, it can train cooperation between groups, the interaction that occurs in the group can be a motivation for other students to answer the given questions. On the other hand, the implementation of this model can also increase students' confidence in conveying the results of discussions and responding to some questions raised by other groups. In addition, a study conducted by (Erna Monika Prasantya \& AR Koesdyantho, 2019) entitled Application of Example Non Example Models on the Theme of Beautiful Togetherness to Improve Learning Outcomes of the fourth grade in SD Negeri 3 Jati Masaran District of Sragen Regency in 2018/2019, which states that cooperation is very necessary in applying this model, it is because in working on the exercise questions and analyzing the pictures requires good cooperation so that the given questions can be solved properly.

Third, embed concepts correctly. It is because the advantage of the example non example model in providing images related to the material and not. The right concept should be embedded in the learning process. However, sometimes errors occur in conveying material directly by the teacher. 
Appropriate concepts can be given in various ways one of them by giving pictures related to the concepts and not. Thus, students will know the right concepts and concepts that are not appropriate individually and guided by the teacher after analyzing the pictures. This is in line with the implementation of the example non example model. (I. and B. S. Kurniasih, 2017) state that the example non example model is a strategy to direct students in explaining a concept through the media used by the teacher. The strategy consists of 2, namely example (correct concept) and non example (incorrect concept). In addition, (Ayu Fitri, 2020), non-example example models are learning methods using examples and steps used to anticipate so students can define concepts by using non-sample and non-example concepts. After that, students will classify the two strategies based on the existing concepts. Video media was used as an interesting media. Video media can attract students' interest to learn so that students learn through relaxing, displaying videos, learning and it became more efficient both from space, time, and messages so that learning can be continued by conveying material that is not yet understood or by discussing video that has been aired ( Khairani Miftahul, Sutisna, 2019). The presented material by the teacher is packaged into interesting videos for students to see and hear.

So it can be said that video media assisted non-example example learning has a positive effect on the learning process because this model has fatigue compared to other model, namely (1) Students can practice critical thinking by analyzing video. (2) Students understand the usefulness of the concepts that have been implanted related to the basic competencies. (3) Students are allowed to communicate their opinions about images that have been analyzed based on basic competencies, (4) students work more together and can develop their social skills. (5) The learning process is more interesting because students can immediately see and observe the material provided as outlined in the video. (6) Foster student interest in the learning process.

\section{Conclusion and Suggestion}

Based on the results and discussion, it can be concluded that there are significant differences in learning outcomes between students who are taught by video media assisted example non example learning model and students who are taught by video media assisted discovery learning model in the mathematics subject of the fifth grade elementary school Cluster IV Buleleng District School Year 2019/2020. It can be seen from the average value of the post-test experimental group and the control group. The experimental group is 73.40 and the control group is 37,07 . So the average value of the mathematics learning outcomes of the experimental group is greater around (73.40)> the control group (37.07) with a difference of 36.33. In addition, it can be seen from the average score of students' posttest results and testing using the $t$-test with details of tcount $=7.78$ and table at a significance level of $5 \%=$ 2.021. The results of the analysis show that $t_{\text {coun }}>t$ table, so the results of the study are significant. It means that there are significant differences in learning outcomes between students who apply video media assisted example non example model and students who apply video media assisted discovery learning model. It shows that video media assisted example and non example learning model affect mathematics learning outcomes of the fifth grade students Cluster IV Buleleng District. In addition, the example non example model combined with video media has a good influence on learning outcomes improvement in mathematics, it can improve critical thinking and cooperation as well as define the right concepts about material cube and blocks. The following suggestions can be given to every party: Teachers should be innovative in implementing learning by changing the models related to the situation, conditions, and subject matter. For other researchers, it is suggested that the results of this study can be used as references or study material to conduct research or find out other learning activity innovations.

\section{References}

Ahen Hestavia, Syafdi Maizora, N. A. Y. (2019). Perbandingan hasil belajar antara model pembelajaran examples non examples dengan pembelajaran saintifik. Jurnal Penelitian Pembelajaran Matematika Sekolah (JP2MS), 3(1), 120-128.

Aisyah Wiyono, Mustamin Anggo, K. (2018). Pengaruh Kecerdasan Emosional Terhadap Hasil Belajar Matematika Siswa Kelas VIII MTs Negeri Kendari. 6(2), 113-126.

Ardiansah, F. (2019). Pengaruh penggunaan media video terhadap minat dan hasil belajar siswa kelas xi pada pelajaran pai di SMA YPI Tunas Bangsa Palembang. JKTP Jurnal Kajian Teknologi Pendidikan, 2(1), 56-70. https://doi.org/http://dx.doi.org/10.17977/um038v2i12019p001

Aris, S. (2014). Model pembelajaran Inovatif Dalam Kurikulum 2013. In 1 (Issue). Yogyakarta: AR-ruz media. 
Ariyanti, I., \& Nurmeidina, R. (2019). Pelatihan Model Pembelajaran Quick on the Draw Dan Savi Bagi Guru Matematika Smp Sekabupaten Banjar. Selaparang Jurnal Pengabdian Masyarakat Berkemajuan, 2(2), 5. https://doi.org/10.31764/jpmb.v2i2.867

Ayu Fitri. (2020). Pengaruh Model Example Non Example Terhadap Kemampuan Pemahaman Konsep Bangun Datar pada Siswa Kelas IV di Sekolah Dasar Ayu Fitri The Effect of Non Example Example Models on the Ability to Understanding Flat Build Concepts in Class IV Students in Primary. Jurnal SEkolah Dasar, 5(1), 38-48.

Deliany, N., Hidayat, A., \& Nurhayati, Y. (2019). Penerapan Multimedia Interaktif untuk Meningkatkan Pemahaman Konsep IPA Peserta Didik di Sekolah Dasar. Educare, 17(2 SE-Research), 90-97. https://doi.org/10.36555/educare.v17i2.247

Erna Monika Prasantya \& A.R. Koesdyantho. (2019). Penerapan model example non example pada tema indahnya kebersamaan untuk meningkatkan hasil belajar kelas IV SD NEGERI 3 Jati Kecamatan masaran Kabupaten Sragen tahun pelajaran 2018/2019.

Herawati, Anisa, Nurul Astuty Yensi B2, R. (2019). Pengaruh hasil belajar matematika siswa dengan mengunakan model pembelajaran example non example di SMP N 7 Kota Bengkulu. Jurnal Penelitian Pembelajaran Matematika Sekolah (JP2MS), 3(1), 58-65.

Jannah, R., \& Morina, C. (2020). Kemampuan Siswa dalam Mengajukan Dugaan dan Melakukan Manipulasi Matematika melalui Model Discovery Learning di Sekolah Menengah Aceh. 5(1), 70-78.

Khairani Miftahul , Sutisna, S. S. (2019). Studi meta-analisis pengaruh video pembelajaran terhadap hasil belajar peserta didik. Jurnal Biolokus, 2(1).

Koyan. (2012). Statistik Pendidikan Teknik Analisis Data Kuantitatif. Undiksha Press.

Kurniasih, dan B. S. (2014). Sukses Mengimplementasikan Kurikulum 2013. Kata Pena.

Kurniasih, I. dan B. S. (2017). Ragam Pengembangan Model Pembelajaran. Kata Pena.

Lisnani. (2019). Pengaruh model pembelajaran example non example. 3(1), 76-82.

Lus Viana Dewi, Mochammad Ahied, Irsad Rosidi, F. M. (2019). Pengaruh aktivitas belajar terhadap hasil belajar siswa menggunakan model pembelajaran discovery learning dengan metode scaffolding Lus. Jurnal Pendidikan Matematika dan IPA, 10(2), 299-213. https://doi.org/ 10.26418/jpmipa.v10i2.27630

Lusiani, N. M. (2019). Pengaruh Model Pembelajaran Examples Non Examples Berbantuan Media Film Edukatif Terhadap Keterampilan Menulis Bahasa Indonesia Siswa Kelas IV SD Gugus IV Mengwi Tahun Ajaran 2018/2019. Skripsi (tidak diterbitkan) Jurusan PGSD Undiksha.

Ningrat, S. P., \& Sumantri, M. (2018). Kontribusi gaya belajar dan motivasi belajar terhadap hasil belajar bahasa indonesia siswa. 2, 145-152.

Noviasari, L., Harjono, N., \& Artikel, I. (2019). Meta-analisis pengaruh model pembelajaran kooperatif tipe example non example terhadap hasil belajar IPA Abstrak. Janacitta : Journal of Primary and Children's Education, 2(1), 33-38.

Oktavia, P., Sari, W., Wardani, N. S., \& Prasetyo, T. (2019). Pengaruh Pembelajaran Saintifik Example Non Example Terhadap Minat Belajar. Jurnal Ilmiah Sekolah Dasar, 3(3), 324-331.

Rinaldy, D. A. (2019). Pengaruh Model Problem Based Learning (Pbl) Berbantuan Media Video Terhadap Hasil Belajar Siswa Kelas IV SD (Kuasi Eksperimen di kelas IV SD Negeri 024 Coblong Kota Bandung Tahun Pelajaran 2019/2020. http://repository.unpas.ac.id/45359/

Sarah, S. (2017). Upaya meningkatkan hasil belajar matematika melalui strategi pembelajaran cooperative learning. 4(2), 1-15.

Suarjana \& Japa. (2015). Pendidikan Matematika III. Undiksha.

Sudjana. (2010). Penilaian Hasil Proses Belajar Mengajar. PT. Raja Grafindo Persada.

Suyanti, Putri, N. H., \& Sunarya, D. T. (2017). Jurnal pena ilmiah: vol 2, No 1 (2017). Jurnal Pena Ilmiah, 2(1), 2051-2060. https://doi.org/https://doi.org/10.17509/jpi.v2i1.10771

Syarifah Habibah. (2016). Penggunaan model pembelajaran examples non examples terhadap 
ketuntasan hasil belajar siswa pada materi tokoh-tokoh pergerakan nasional kelas. Jurnal Pesona Dasa, 3(4), 54-64.

Tasmalina, T., \& Prabowo, P. (2018). Pengaruh Media Video Pembelajaran Terhadap Hasil Belajar Siswa Pada Sub Materi Spermatophyta di SMA Swasta Nurul Amaliyah Tanjung Morawa Tahun Pembelajaran 2015/2016. Best Journal (Biology Education, Sains and Technology), 1(1), 14-20. https://doi.org/10.30743/best.v1i1.621

Teresia Olivia Oennus, Erni, R. K. H. (2019). Pengaruh penerapan model pembelajaran example non example terhadap hasil belajar matematika Oleh Teresia Olivia Oennus, Erni, Ramadhan Kurnia H.1.

Thamrin, Y. (2019). Efektivitas Penerapan Model Kooperatif Tipe Example Non Example dalam Pembelajaran Matematika Siswa Kelas VII SMP. 3(1), 92-100.

Ulhusna, M., \& Diana, S. (2020). Permainan Ludo untuk Meningkatkan Keterampilan Kolaborasi Siswa dalam Pembelajaran Matematika. 4(1), 130-138.

Widoyoko. (2011). Evaluasi Program Pembelajaran. Pustaka Pelajar.

Yunita, D., \& Wijayanti, A. (2017). Pengaruh Media Video Pembelajaran Terhadap Hasil Belajar Ipa Ditinjau Dari Keaktifan Siswa. Sosiohumaniora: Jurnal Ilmiah Ilmu Sosial Dan Humaniora, 3(2), 153-160. https://doi.org/10.30738/sosio.v3i2.1614 